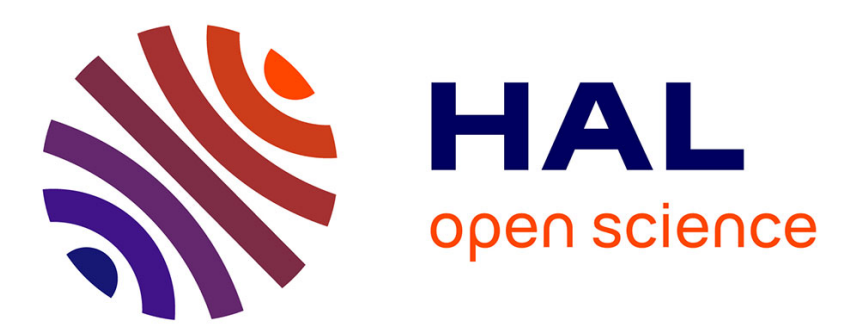

\title{
Advocacy coalitions and protected areas creation process: Case study in the Amazon
}

\author{
Sandra Nicolle, Maya Leroy
}

\section{To cite this version:}

Sandra Nicolle, Maya Leroy. Advocacy coalitions and protected areas creation process: Case study in the Amazon. Journal of Environmental Management, 2017, 198 (1), pp.99-109. 10.1016/j.jenvman.2017.04.035 . hal-01529019

\section{HAL Id: hal-01529019 \\ https://hal.science/hal-01529019}

Submitted on 11 Dec 2019

HAL is a multi-disciplinary open access archive for the deposit and dissemination of scientific research documents, whether they are published or not. The documents may come from teaching and research institutions in France or abroad, or from public or private research centers.
L'archive ouverte pluridisciplinaire HAL, est destinée au dépôt et à la diffusion de documents scientifiques de niveau recherche, publiés ou non, émanant des établissements d'enseignement et de recherche français ou étrangers, des laboratoires publics ou privés. 


\section{Advocacy coalitions and protected areas creation process: Case study in the Amazon}

\section{Sandra Nicolle, Maya Leroy}

AgroParisTech \& Montpellier Recherche en Management, France

\section{Introduction}

Protected areas are management arrangements, whose aim is the protection of natural ecosystems in a specific geographic area. Today they are the main public policy tool for "in situ" ecosystem protection worldwide and they account for more than $15 \%$ of land in the world. They are very diverse, and their diversity reflects the different opinions concerning the means required to protect the environment.

Many researches have been led recently on the topic of protected areas. A rapid review of recent literature shows that these researches mainly aim at finding means to improve protected areas efficiency, but in many different ways. Some are oriented toward the definition or analysis of indicators of management efficiency (Addison et al., 2015; Aung et al., 2004; Calado et al., 2016; Cook et al., 2014), or of financial efficiency (Cornejo et al., 2016). Others are more interested in direct management and propose technical tools in order to facilitate manager's work and decision-making (D'Antonio et al., 2013; Del Carmen Sabatini et al., 2007; Kidd et al., 2015; Lin and Li, 2016; Lopez y Royo et al., 2009).

Another category of researches aims at analysing the conditions for a protected area to be better accepted at the local scale (Allendorf et al., 2012; Apostolopoulou et al., 2012; Arjunan et al., 2006; Jones et al., 2012; Liu et al., 2010). These works are mainly based on the analysis of local people perceptions and strongly stress the importance of participation in the construction and management of protected areas.

All of these researches are mainly based on quantitative data, and focus on the analysis of situations at the present time, and mainly at the local scale. The current management practices and the managers' ability to create social acceptance of the protected area at the local scale are supposed to explain their environmental efficiency. Only very few papers analyse management situations over long period of time (Aung et al., 2004). However, long-time analysis is very important to understand and manage not only the conflicts that frequently accompany the creation and management of protected areas (Buisson and Dutoit, 2006) but also the 
inner structure and action capacity of these protected areas.

Moreover, if some authors discuss the legitimacy on some specific models of protected areas, and in particular defend participative ones over those that promote a strict protection of biodiversity (Hutton et al., 2005), the strategic processes that are underneath the creation processes of these areas are hardly ever documented. The dominant discourse is that protected areas are top-down policies, imposed by the state, not adapted to the local context, and that reproduce the North-South model of domination (Banerjee, 2003), which would partly explains their failure to protect the environment.

To question this discourse, we are interested in analysing the creation processes of protected areas, in order to understand how environmental actors manage or not to mobilize allies and strategic resources to influence public policy making. Indeed, since the years 1970, we observe a reshaping of decision and territorial management processes. In terms of territorial management, it implies the action of various actors (state, NGOs, firms, scientists ...) that contribute to decision processes. It also implies the emergence of strong conflicts between various policy sectors. Indeed agriculture, mining, forestry or conservation sectors have difficulties to coordinate as they carry very different views on what is the right thing to do on the territory (Sarvasova et al., 2013).

The objective of this work is therefore to analyse how protected areas emerge thanks to the action of coalitions that defend environmental stakes.

The case study is the French and Brazilian Amazon and we mobilize an actor-based theory to understand the creation of various types of protected areas. The theoretical framework is the Advocacy coalition framework (A.C.F.). Indeed, Sotirov and Memmler (2012) show that the A.C.F. is particularly adapted to analyse natural resources management policies. Furthermore, our work in environmental management is not only interested in the coalitions themselves, but also to the relationship between these coalitions and the concrete management arrangement that emerge (outputs).

After the presentation of the theoretical framework and methodological approach, we present the historical process of protected areas creation for three different models, in a comparative way between French and Brazilian case. These results allow us to test our hypotheses that are then discussed in the discussion part.

\section{Theoretical framework and methodological approach}

\subsection{Analysis of changes in environmental management policies:} advocacy coalition framework (ACF) inputs

The advocacy coalition framework (Sabatier, 1988; Sabatier and Weible, 2007) is interested in the necessary conditions for the occurrence of change in public policies. It defends the idea that, in a given policy field, different coalitions of actors compete. The coalitions are composed of individuals (civil servants, scientists, journalists, private actors, etc.) who share the same beliefs concerning the policy field. The core beliefs of a coalition are very stable over time, whereas secondary aspects like management tools can be modified more easily. The advocacy coalition framework shows that although a change in public policies that only involves small progressive changes in a dominant paradigm can occur without a rupture and over a long period, a radical change in a dominant paradigm requires a rupture in the political system, which is more often enabled by a change in the external conditions (change of government, a change in public opinion, etc.) (Fig. 1).

By applying this framework, we are specifically interested in revealing the processes by which actors promoting environmental issues manage to transform their ideas into territorialized public policies e protected areas e which conflict with other land uses.

The policy subsystem we are interested in is the territorial management of the Brazilian Amazon region. Indeed, despite the discourses on forest conservation, the Food and Agriculture Organization (F.A.O.) states in 2010 that more that 60 millions ha of the Amazon forest have been converted to other land uses (agriculture, mining, energy, roads ...). During the past 50 years, both massive development programs and conservation ones have been led in the Amazon region. This expresses what has been called the schizophrenic attitude of Brazil government (Aparecida de Mello and Thery, 2003; Brown and Purcell, 2005; Taravella and De Sartre, 2006).

The idea that economic development of the Amazon region necessarily implies deforestation (called "land valorisation") dates back to the colonial period. Programs of forest conservation appeared in the beginning of the XXth century and became popular in the seventies, when development programs promoting deforestation grew extremely intensive. Protected areas are the main tools promoted for forest conservation.

The objective of this paper is to study the emergence of these management arrangements (protected areas), i.e. the coalitions that promoted them and the institutional result.

We make the following hypotheses:

H1 e Coalitions of actors at the origin of protected areas creation were all opposed to destruction of forestland but don't necessarily share the same objectives.

$\mathrm{H} 2$ e The success of coalitions to build the protected area they promote depends on internal and external factors like the sociopolitical context.

$\mathrm{H} 3$ e The action capacity of the protected areas depends on the strength of pleading coalitions.

\subsection{The case study}

Our case study is located in the northern part of the Amazonian forest, on the Guiana Shield (Fig. 2), at the border between French Guiana, a French overseas department, and Amapa, a Brazilian state. They share a common border $730 \mathrm{~km}$ long. These territories present vast and well-preserved forest ecosystems in a context of rapid socio-economic change (population growth, construction of infrastructure, etc.). Even though they belong to different countries, they resemble each other ecologically and geographically, thus justifying the use of a comparative approach (Boudoux d'Hautefeuille, 2012; Lezy, 2000). For us, the most important aspect is that they present a large number of protected areas.

The interest of this comparative approach between two countries is to test the influence of the socio-political and historical context on the composition, action and success of the coalitions.

\subsection{Methodological approach and data production}

This analysis is mainly based on the production of qualitative data, in order to analyse the complexity of the situations, and the influence of the social, institutional and historical context. Moreover, qualitative approaches are components of critical approaches, based on a sociological, or even socio-anthropological, dimension to the field work (Dumez, 2013; Olivier De Sardan, 2015).

Data was collected during a doctoral thesis over a period of two years. Our approach favours long-term investment in the field and thorough inquiries, it crosses interviews, direct observations, and information from written or visual sources (see Table 1). All through the research process, systematic crossing of the information was at the basis of producing results. This enables hypotheses 


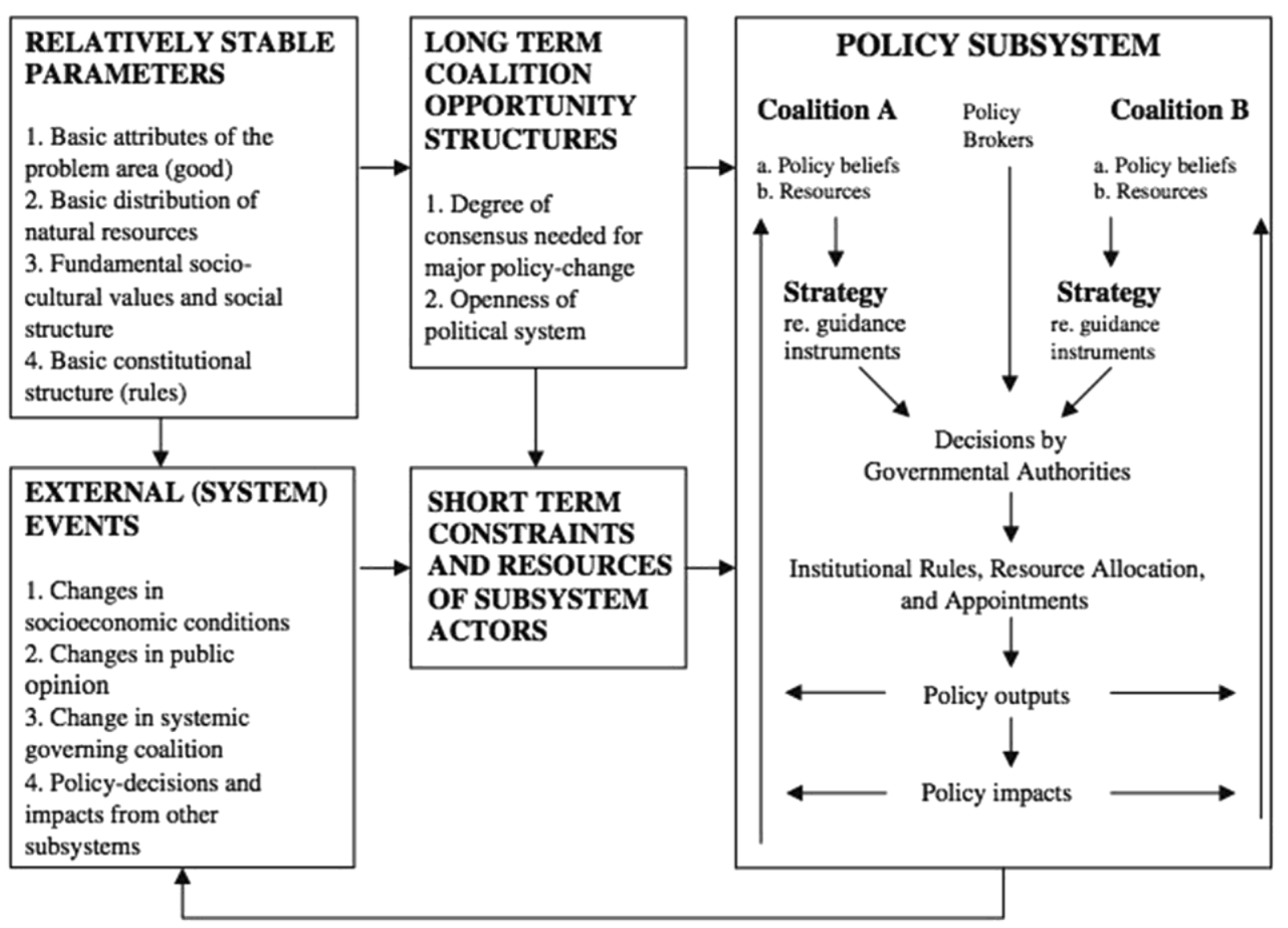

Fig. 1. Advocacy coalition framework diagram (Sabatier and Weible, 2007).
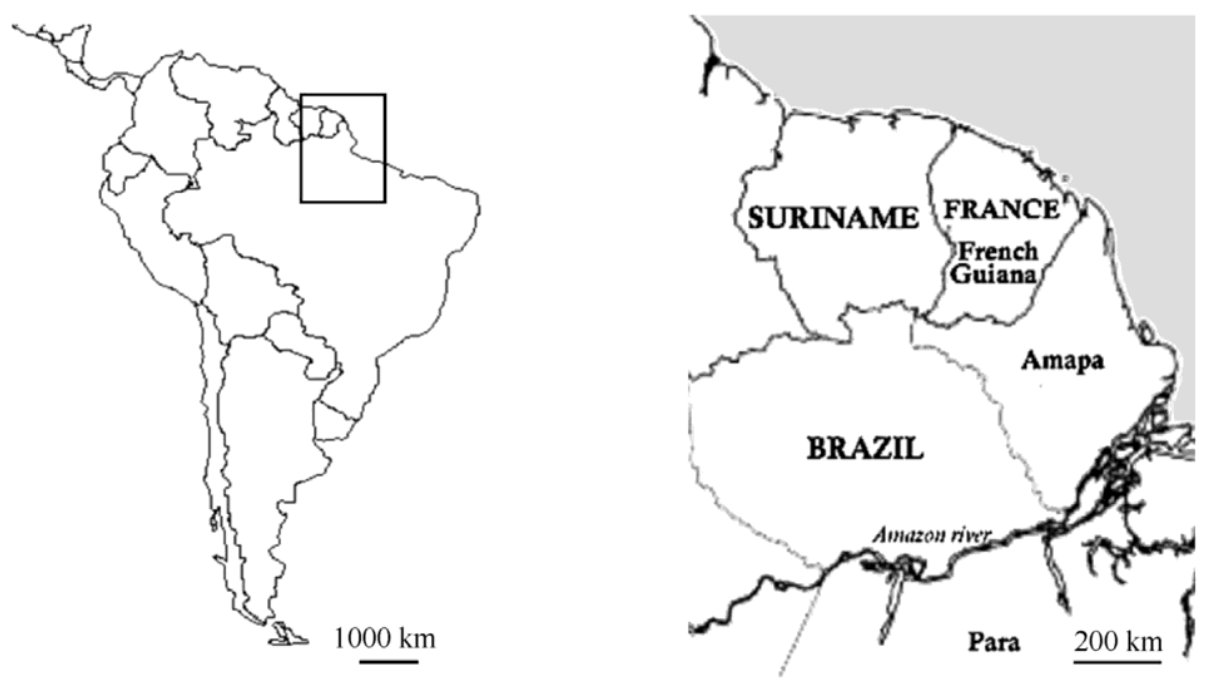

Fig. 2. Location of the case study: French Guiana and Amapa (Brazil) in South America.

to be formulated concerning organisations and actors' leeway, which can be tested later, in other interviews. The aim is to reach information saturation, i.e. when new data no longer provide useful information for analysis.

The research was organised in several steps that structure the findings section.

First we identified all the protected areas present in the study area. Through the analysis of legislative texts and management documents, we classified them depending on their management objectives. The question was: "In what way does this protected area intend to protect forestland?".

The second step consisted in understanding the stories of their creation. We analysed it through the lens of ACF in order to understand what coalitions allowed these new public tools to be created.

The third step consisted in analysing the differences between 
Table 1

Methods combined for data production.

\begin{tabular}{|c|c|c|c|}
\hline Data source & & Data production & Comments \\
\hline Interviews & Semi-directive interviews & $\begin{array}{l}120 \text { interviews, lasting from } 45 \text { min to } 3 \mathrm{~h} \\
\text { Most were recorded. They were fully transcribed. }\end{array}$ & $\begin{array}{l}\text { Interviews were in French and in Portuguese. } \\
\text { They were classified in } 3 \text { categories: } \\
\text { - Historical interviews, to understand the construction of } \\
\text { protected areas; } \\
\text { - Interviews with managers, to understand the way } \\
\text { protected areas work; } \\
\text { - Interviews with local people, to understand their vision of } \\
\text { the creation process. }\end{array}$ \\
\hline \multirow[t]{4}{*}{ Documents } & Archives & $\begin{array}{l}\text { Collection of information in archives in documentation } \\
\text { centres }\end{array}$ & $\begin{array}{l}\text { Made it possible to trace the process of creation of protected } \\
\text { areas. }\end{array}$ \\
\hline & Legal documents & $\begin{array}{l}\text { All laws on the protected areas studied (and the changes } \\
\text { they have undergone since their creation) }\end{array}$ & $\begin{array}{l}\text { Information collected from legal Internet sites in both } \\
\text { countries. }\end{array}$ \\
\hline & Management documents & $\begin{array}{l}\text { Internal and external management documents in protected } \\
\text { areas. }\end{array}$ & $\begin{array}{l}\text { Provide information on management orientations and } \\
\text { strategies in the different protected areas. }\end{array}$ \\
\hline & Scientific literature & Multidisciplinary literature on protected areas. & / \\
\hline
\end{tabular}

these different processes in both countries studied.

\section{Findings}

The first section of results (3.1.) describe the process of category building. Then, the other result sections (3.2., 3.3. and 3.4) describe the actors' coalitions that stand behind each protected area category in both territories.

\subsection{Identification of protected areas and typology building}

Table 2 presents all the official categories of protected areas existing in Amapa and French Guiana (managed at a national or regional scale). As it was too complicated to handle such a number of categories, we decided to group them in function of their core values for environmental management. We came up with four main categories: Strictly protected areas (S.P.A.), Tribal Protected areas (T.P.A.), Local development areas (L.P.A.) and Sustainable forest management areas (S.F.M.A.). Their characteristics, and their spatial organization are presented in Table 3 and in Fig. 3.

After building this first typology, we tried and understand who acted in favour of the creation of these protected areas. Because of time we only focused on three of the categories: Strictly protected areas (S.P.A.); Tribal protected areas (T.P.A.) and Sustainable Forest Management areas (S.F.M.A.). The diachronic study of the coalitions at the origin of the creation of protected areas revealed that for each type of protected area a specific coalition was built. The actors involved, and the management objective they supported indeed differ depending on the coalition's core beliefs.

\subsection{Coalition of ecologists and environmental public administration: creation of strictly protected areas}

In Brazil, the economic development plans of the late 1950s were based on massive colonization of the Amazonian forest. Between 1956 and 1961, 20,000 km of roads were built, as well as $826 \mathrm{~km}$ of railways, and the electricity production raised of $65 \%$ (Campos, 2009). These policies alarmed the members of the main Brazilian environmentalist association, the Nature Conservation Federation (Portuguese acronym F.B.C.N.). In relation with international scientists, they started to publish scientific papers in the conservation field and proposed a first methodology to design

Table 2

Protected areas present in our case study and reclassification under 4 management categories.

\begin{tabular}{ll}
\hline Amapa & French Guiana \\
\hline 1 Ecological station - S.P.A. & 5 National nature reserves - S.P.A. \\
1 Biological reserve - S.P.A. & 1 Regional nature reserve - S.P.A. \\
2 National parks - S.P.A. & 1 National park e S.P.A.and L.P.A. \\
2 Public forests - S.F.M.A. & 1 Biological reserve - S.P.A. \\
1 Area for environmental protection - L.P.A. & 13 littoral areas under protection - L.P.A. \\
1 Sustainable development reserve - L.P.A. & 1 Regional nature park - L.P.A. \\
1 Extractivist reserve - L.P.A. & 1 public forest - S.F.M.A. \\
5 Indigenous territories e T.P.A. & 13 areas for traditional population's use - T.P.A. \\
\hline
\end{tabular}

Table 3

Core values and policy objectives of our management categories.

\begin{tabular}{|c|c|c|}
\hline Protected area & Core values & Policy objectives \\
\hline «Strictly » protected areas e S.P.A. (Fig. 3: Green) & $\begin{array}{l}\text { "Most human activities are not compatible with } \\
\text { ecosystem preservation. " }\end{array}$ & $\begin{array}{l}\text { Maintenance of the integrity of ecosystems, with } \\
\text { minimal forest fragmentation or disturbance. }\end{array}$ \\
\hline « Tribal » protected areas e T.P.A. (Fig. 3: Orange) & $\begin{array}{l}\text { «Traditional practices of tribal population conserve } \\
\text { forest ecosystems» }\end{array}$ & $\begin{array}{l}\text { Maintenance of tribal populations way of living } \\
\text { based on sustainable agriculture and hunting. }\end{array}$ \\
\hline « Local development areas»- L.P.A. (Fig. 3: Blue) & $\begin{array}{l}\text { «Lacal activities ensure an economic development } \\
\text { respectful of the environment » }\end{array}$ & Enhancement of local economic activities \\
\hline $\begin{array}{l}\text { «Sustainable forest management » - S.F.M.A. (Fig. } 3 \text { : } \\
\text { Red) }\end{array}$ & $\begin{array}{l}\text { "Timber production in public forests gives an } \\
\text { economic value to the forest, and prevents its } \\
\text { conversion to other uses. » }\end{array}$ & $\begin{array}{l}\text { Long-term maintenance of the forest cover, } \\
\text { allowing continuous timber production. } \\
\text { Road construction is necessary, but impacts can be } \\
\text { limited by drawing up technical guidelines. }\end{array}$ \\
\hline
\end{tabular}




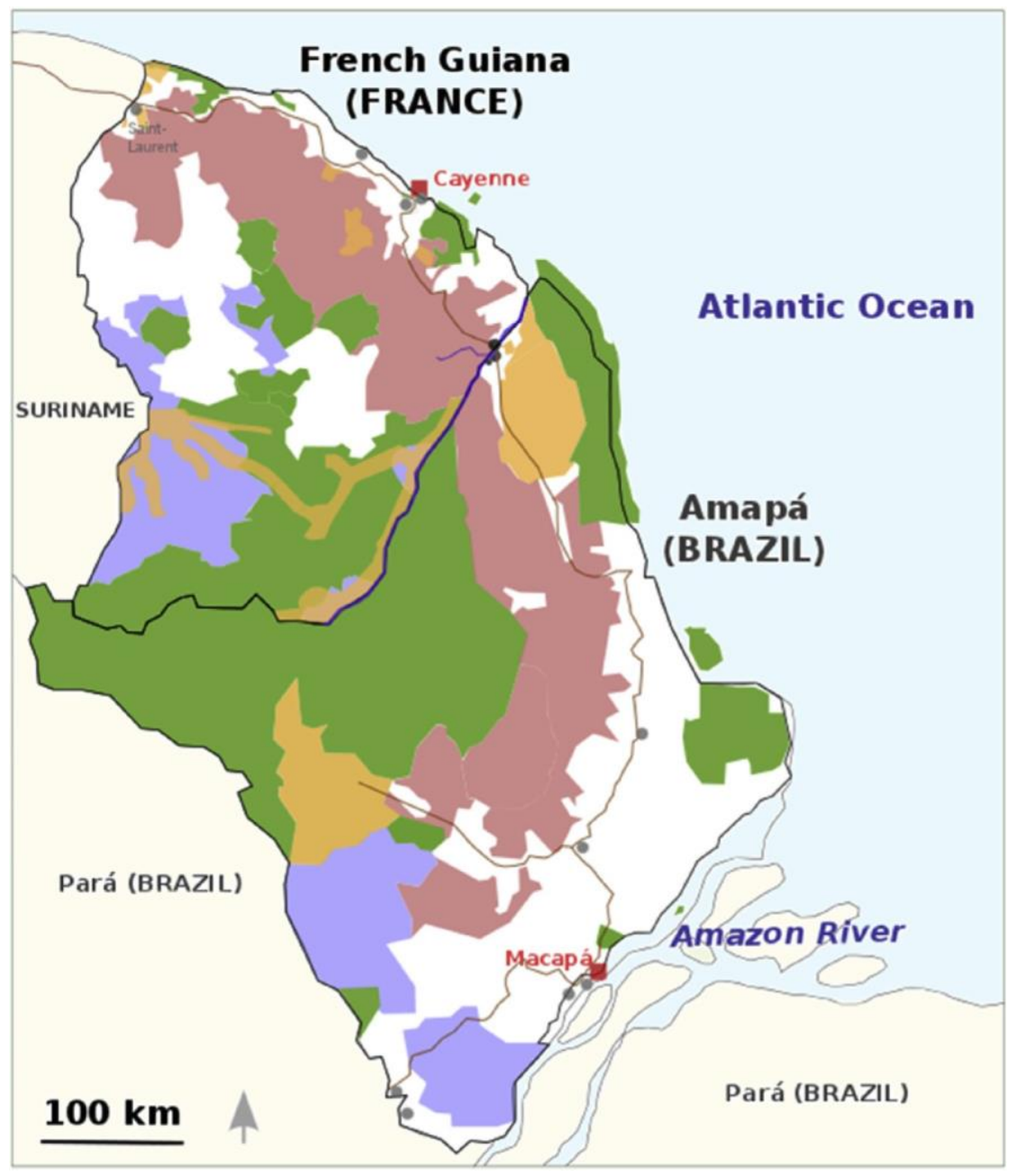

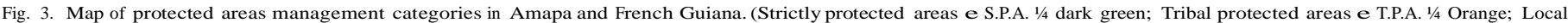

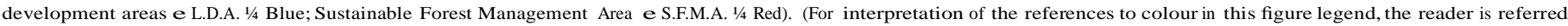
to the web version of this article.)

protected areas at the national scale.

A decade later, in the context of the 1972 Stockholm conference, international pressure persuaded the Brazilian dictatorial government to create dedicated environmental institutions. The first Brazilian plans for protected areas emerged from the alliance between the civil servants who worked in these new institutions and acted within the dictatorial government, and scientists mobilised by the F.B.C.N. (Drummond and Franco, 2013). Three of these protected areas were created at this moment in Amapa.

In French Guiana, the same alliances formed with the involvement of a local naturalist NGO (Sepanguy), a national NGO (Sepanrit), local scientists and local representatives of the Ministry of the environment. The local NGO used scientific expertise to oppose the implementation of the Plan Vert in the 1970s, which aimed at establishing huge paper industries and large-scale farms. The successive proposals made by the coalition failed because of repeated opposition by political actors in French Guiana (Sanite, 1992). However, the nomination of a French Guianese citizen member of the NGO Sepanguy - as the director of the newly created environmental directorate, in the context of the upcoming Rio Earth Summit in 1992, allowed the deadlock to be broken. It led to the creation of five national natural reserves (based on French legislation). The process of creation of a large national park was also launched in the south of French Guiana. The protected areas created by these coalitions are «strictly protected areas » (categories I to IV of International Union for Nature Conservation e I.U.C.N. classification), and their environmental action is based on strict limits on most human activities that could affect the ecosystems.

Table 4 summarises the contribution of the actors involved in the coalitions.

It shows that the same categories of actors were mobilised in the two countries, but that the scales were different. In Amapa, the coalition for preservation is national, aimed at creating protected areas throughout Amazonia, whereas in French Guiana, mainly local actors were mobilised.

In both cases, the coalitions who supported ecosystem preservation were not the dominant ones in the political system. Two main factors allowed the emergence of their claims and their transformation into public policies.

The first was a change that occurred outside the national systems: international recognition (through the Stockholm and Rio conferences) of the need to take natural ecosystems into account. This led to pressure (financial pressure in Brazil, and symbolic pressure in France) on national governments to take environmental issues into account. This context created opportunities for coalitions that were already structured to support ecosystem protection (NGOs and scientists). The second factor (which was a consequence of the first) was the creation of public institutions 
Actors involved in the "strict preservation" coalition.

\begin{tabular}{|c|c|c|c|}
\hline Action level & Actors & Actions within Amap & Actions within F. Guiana coalition \\
\hline \multirow[t]{3}{*}{ International level } & Scientists & Scientific methods for conservation & I \\
\hline & NGOs & Media alerts & / \\
\hline & Institutions & Pressure on the government & Pressure on the government \\
\hline \multirow[t]{3}{*}{ National level } & Scientists & Data production on ecosystems & Data production on ecosystems \\
\hline & NGOs & Partnership with administration & Media alerts \\
\hline & Env. administration & Creation of protected area & Creation of protected areas \\
\hline \multirow[t]{3}{*}{ Local level } & Scientists & / & Data production on ecosystems \\
\hline & NGOs & / & Local and national lobbying \\
\hline & Env. administration & Creation of protected areas & Creation of protected areas \\
\hline
\end{tabular}

specialised in environmental matters. This made it possible for existing coalitions to obtain support from within the political system. However, the transformation of their claims into public policies was limited by the interest of other coalitions in exploiting natural resources (mainly mining resources). As a consequence, protected areas were mainly created on territories which were considered to be of little economic interest. In French Guiana, resistance from local political actors limited the potential area concerned by strictly protected areas. Indeed, these protected areas are considered as policies which freeze all potential economic development, and represent neo-colonialist intentions of the central state (France).

The analysis of the strictly protected areas shows that in both cases, the coalitions created similar management arrangements. The protected areas are based on a law that forbids the majority of economic uses (but most often allow scientific research and tourism) and they are managed by quite small teams of people employed by the state (sufficient for administrative purposes, but not for physical control of the territories).

3.3. Indigenous population coalition towards official recognition of their territories and practices

In the 1970s, the same huge development projects increased pressure on the Amerindian populations in both countries.

In Brazil, it was to face these threats that the indigenous movement arose, led by anthropologists and indigenists, with the growing support of the indigenous population. Unlike the environmental movement, this movement was created in strong opposition to the dictatorial regime. The indigenist organisations acted at the national level to force a change in the legislation. At the fall of the dictatorial regime, they manage to recognize the specific rights eincluding territorial rights- for Amerindians in the Brazilian constitution (1988). The national movement was connected to the local level to support the political structuring of Amerindians and the demands for the recognition of indigenous territories. This was the context in which the indigenous territories of the Oyapock (border region) were created, as a consequence of the strong opposition of the population to the construction of the national road 156 in their territory. The political structuring of the population, supported by indigenists (in this case state employees living in the indigenous territories and religious organisations) and anthropologists working in Sao Paolo University ended with full recognition of the territories - which were nevertheless crossed by the road.

The indigenous territories created in Brazil were later officially recognized as «protected areas », thanks to the empirical observation of their efficiency in maintaining the forest cover (Nepstad et al., 2006).

In French Guiana, there was less physical violence toward the Amerindian population than in Brazil. However, the anthropologists who worked with these populations strongly defended the need to recognize special territorial rights for them. Despite the reluctance of the local political elite (Grenand and Grenand, 2005), it was thanks to the combination of the scientific data they produced (particularly cartographic data) and administrative support of some local and national civil servants that they managed to create a specific legislative tool that recognized Amerindian people's collective rights to continue their traditional uses of the forest (ZDUC). These areas, which were created a few years later, remain weak from a legislative point of view, and we observed (interviews led in 2011e2012) that the population they target was not fully aware of their existence and objectives (apart in some specific communities).

Table 5 shows that the coalition built in the 1980s in Amapa is part of a national indigenist coalition, and is much better organised than the coalition in French Guiana. In both cases, they succeeded in acquiring specific territorial rights for the Amerindian populations, but the recognition of Amerindian peoples' rights and specificities went much further in Brazil (Constitution) than in French Guiana.

In both cases, the coalitions' main objective was not to protect the ecosystems for themselves, but to protect the natural resources and territories required by the Amerindian populations to live according to their own way of life. The link between their traditional practices and environmental protection has recently been made official in Brazil.

The Brazilian coalition, stronger that the French one, managed to build more assets (constitutional rights, complex networks, specific administration) to design a strategy to respond to growing pressure on the ecosystems. The Brazilian case is symbolic of a multiscale coalition, as it connected very local actors, who were defending their way of life against direct threats, and actors on the international scene, mobilised in favour of the protection of Amazonia. In French Guiana there are no such examples of strong local rallying for the creation of protected areas.

Protected areas based on traditional populations' practices are much more frequent in Brazil than in France. Indeed, the French constitution does not allow official recognition of differences between people based on their origins, which makes it difficult to promote these kinds of protected areas.

\subsection{Shifting paradigms for sustainable exploitation of public forests}

Since the 1990 s, sustainable forest management e i.e. long-term economic gains from the forest, while respecting and maintaining natural resources $e$ is presented as the main solution to save the tropical forests (Leroy et al., 2014).

Sustainably managed public forests are primarily the result of compromises between pre-existing economic activities (forest exploitation), and a new concept that aims at minimizing the 
Table 5

Actors involved in the "Indigenous territorial rights" coalition.

\begin{tabular}{|c|c|c|c|}
\hline Action level & Actors & Actions within Amapa coalition & Actions within F. Guiana coalition \\
\hline $\begin{array}{l}\text { International } \\
\text { level }\end{array}$ & $\begin{array}{l}\text { Global indigenist } \\
\text { movement }\end{array}$ & $\begin{array}{l}\text { Gives legitimacy to local claims; International pressure } \\
\text { (OIT 169) }\end{array}$ & $\begin{array}{l}\text { Gives legitimacy to local claims; International pressure } \\
\text { (OIT 169) }\end{array}$ \\
\hline \multirow[t]{4}{*}{ National level } & Indigenous people & $\begin{array}{l}\text { Interethnic connexions; claims and pressure on the } \\
\text { government. }\end{array}$ & / \\
\hline & Administration & Ability to define indigenous territories & Lobby, law creation \\
\hline & NGOs & Support local movements; lobby & I \\
\hline & Anthropologists & Knowledge production for NGO lobbying & / \\
\hline \multirow[t]{4}{*}{ Local level } & Indigenous people & Local politic organization; Direct actions & Local politic organization; Direct actions \\
\hline & Administration & Local delimitation of indigenous territories & Local implementation of the new law \\
\hline & NGOs & Local support and advice to populations & / \\
\hline & Anthropologists & Knowledge production for delimitation & Knowledge production for delimitation \\
\hline
\end{tabular}

impacts of exploitation on the ecosystems. In both studied territories, there was a progressive change from exclusive economic preoccupations towards sustainable development paradigm. However, the historical context of the creation of public forest for sustainable management is quite different in the two territories.

In French Guiana, changes in the paradigm of forest exploitation occurred progressively, within the forest coalition. Indeed, even though the forest administration has existed since 1931, the French Forest Office became much more active in the planning and control of logging after 1992 (Borde res, 2003), when France signed an international agreement on the exploitation of tropical forests. Throughout the process, the pre-existent coalition between civil servants from the forest office, local and national researchers in forest ecology and forest exploitation firms hardly changed, but the preoccupations evolved little by little towards sustainable management based on the adaptation of the French management tools (forest management plans that take into account fragile natural habitats, reduced impact logging, the introduction of certification etc.) to tropical forest ecosystems.

In Amapa, there was no public forest management until 2005, and the forestry sector was mainly informal. However, public forests have recently been presented by the environmental sector as one of the best solution to limit deforestation in Amazonia, and their implementation is largely supported by the federal state (Barreto and Veríssimo, 2002). In this logic, and with a desire to develop the economic forestry sector, the Amapa state, supported by some local enterprises, created the public forest of the federal state of Amapa. After validation of its management plan in 2014, the opening of forest concessions to private firms began. These firms are responsible for implementing sustainable forest exploitation.

At first glance, the coalitions mobilised are very similar (Table 6). However, in French Guiana, the coalition is mainly articulated around the National Forest Office, which has been working in the territory for more than 40 years. The coalition mobilised existed before the concept of sustainable forest management and before the definition of a permanent public forest. Although many adaptations have been made, the management model was directly inherited from forest management in France, with very strong presence of the state in the planning of exploitation.

In Amapa, public forest exploitation is a new concept, so the actors in the coalition (state services, private actors, NGOs), have no experience in public forest management. The private actors play a very important role in planning exploitation, as they are directly responsible for their concessions.

Finally, in French Guiana, the change from forest exploitation practices which harmed the ecosystems towards a more sustainable exploitation (change mainly initiated at the international level in the 1990 s by big environmental NGOs) did not lead to the emergence of totally new protected areas, but to modifications in the existing management arrangements. In Brazil, national environmental resistance (by NGOs) to the massive agricultural colonization of the forest led to the emergence of public forest concessions, in order to improve control over land tenure, and through the establishment of compromises with foresters.

In both cases, the forestry economic sector is presented as one of the best alternatives to deforestation, and as a practical case study of sustainable development. However, even if sustainable forestry management indeed makes it possible to maintain the forest cover, it always involves degradation of the primary forest being exploited, particularly in terms of biodiversity (Leroy et al., 2014). In the case of previously unfragmented forests like some of those exploited in French Guiana and Amapa, it might not be such an «environmentally friendly » solution after all.

This historical presentation of the coalitions and of the protected areas they managed to create shows that the potential efficiency of management arrangements to protect natural ecosystems

Table 6

Actors involved in the "Sustainable forest management" coalitions.

\begin{tabular}{|c|c|c|c|}
\hline Action level & Actors & Actions within Amapa coalition & Actions within FG coalition \\
\hline $\begin{array}{l}\text { International } \\
\text { level }\end{array}$ & $\begin{array}{l}\text { International NGOs and } \\
\text { institutions }\end{array}$ & $\begin{array}{l}\text { Pressure on Brazil's government to limit } \\
\text { deforestation }\end{array}$ & $\begin{array}{l}\text { Pressure on the French Government for improved forest } \\
\text { policies }\end{array}$ \\
\hline \multirow[t]{4}{*}{ National level } & Administration & Control of illegal exploitation e new law & Funds management improvement \\
\hline & NGOs & Expertise, forest monitoring and lobbying & Lobby and alerts \\
\hline & Scientists & Define rules for forest management & / \\
\hline & Private firms & Pressure to get access to timber & / \\
\hline \multirow[t]{3}{*}{ Local level } & Administration & Give access to land for forest exploitation & Plan and control forest exploitation \\
\hline & Scientists & Define areas for forest exploitation & Define rules for forest management \\
\hline & Private firms & Pressure to get access to timber & Improve practices \\
\hline
\end{tabular}


Comparative synthesis of the coalition composition and action.

\begin{tabular}{|c|c|c|c|c|c|c|}
\hline Coalition & Core value & Area & Composition & $\begin{array}{l}\text { Main scale of } \\
\text { action }\end{array}$ & $\begin{array}{l}\text { Duration of coalition } \\
\text { before creation (years) }\end{array}$ & Reasons of success \\
\hline \multirow[t]{2}{*}{$\begin{array}{l}\text { Strict protection } \\
\text { S.P.A. }\end{array}$} & \multirow[t]{2}{*}{$\begin{array}{l}\text { "Most human activities } \\
\text { are not compatible with } \\
\text { ecosystem preservation. » }\end{array}$} & A. & $\begin{array}{l}\text { Scientists } \\
\text { NGOs } \\
\text { State administration }\end{array}$ & $\begin{array}{l}\text { National } \\
\text { International }\end{array}$ & Env. 20 & $\begin{array}{l}\text { International pressure. } \\
\text { Preexistence of scientific } \\
\text { data. }\end{array}$ \\
\hline & & F.G. & $\begin{array}{l}\text { Scientists } \\
\text { NGOs } \\
\text { State administration }\end{array}$ & $\begin{array}{l}\text { Local } \\
\text { National }\end{array}$ & Env. 30 & $\begin{array}{l}\text { Environmentalist actors } \\
\text { inside the government. }\end{array}$ \\
\hline \multirow[t]{2}{*}{$\begin{array}{l}\text { Tribal pop. Protection } \\
\text { T.P.A. }\end{array}$} & \multirow[t]{2}{*}{$\begin{array}{l}\text { «Traditional practices of } \\
\text { tribal population conserve } \\
\text { forest ecosystems. » }\end{array}$} & A. & $\begin{array}{l}\text { Scientists \& medias } \\
\text { NGOs } \\
\text { State administration } \\
\text { Local populations }\end{array}$ & $\begin{array}{l}\text { Local } \\
\text { National } \\
\text { International }\end{array}$ & Env. 30 & $\begin{array}{l}\text { Fall of dictatorship } \\
\text { Joint action of local fieldwork } \\
\text { and lobbying. }\end{array}$ \\
\hline & & F.G. & $\begin{array}{l}\text { Scientists } \\
\text { State administration }\end{array}$ & Local National & Env. 20 & $\begin{array}{l}\text { Scientific data } \\
\text { National sensibilization }\end{array}$ \\
\hline \multirow[t]{2}{*}{$\begin{array}{l}\text { Sustainable forest management } \\
\text { S.F.M.A. }\end{array}$} & $\begin{array}{l}\text { Timber production in } \\
\text { public forests gives an } \\
\text { economic value to the }\end{array}$ & A. & $\begin{array}{l}\text { NGOs } \\
\text { State administration } \\
\text { Industries }\end{array}$ & $\begin{array}{l}\text { National } \\
\text { Local }\end{array}$ & Env. 15 & $\begin{array}{l}\text { Trade-off between economic } \\
\text { and environmental interest. }\end{array}$ \\
\hline & $\begin{array}{l}\text { forest, and prevents its } \\
\text { conversion to other uses. » }\end{array}$ & F.G. & $\begin{array}{l}\text { State administration } \\
\text { Researchers } \\
\text { Industries } \\
\text { NGO }\end{array}$ & $\begin{array}{l}\text { National } \\
\text { Local }\end{array}$ & Env. 10 & $\begin{array}{l}\text { International pressure. } \\
\text { State action }\end{array}$ \\
\hline
\end{tabular}

is closely linked to the management paradigms supported by the coalitions, but also to the way the coalitions manage to efficiently transform their claims into public policies.

\section{Discussion}

In order to lead a comparative analysis and to discuss the hypothesis, Table 7 synthetises the main results concerning the coalitions.

\subsection{Compared analysis of the coalitions}

First, allowing some new logics of territorial management public policies is a process that takes a long time to emerge. It takes even longer when there are strong oppositions to the creation of the protected area. This explains why the sustainable forest management areas were created much faster than others. Indeed, these areas defend some sustainable development logics, based on an economic sector development and are therefore less conflicting than areas that go against economic interests of strong sectors (like mining for example). To go one step further, we could say that coalitions defending strictly protected areas or indigenous territories were carrying new ideas, in opposition to the mainstream development logic: they ask for a total shift of core value for the territory management. In the case of forest management areas, the economic logic of forest exploitation already existed and had a place on the territory: it is therefore more a progressive shift of values, that adds environmental and social components to existing coalitions than a radical new proposal. Finally, if we compare the general logic of the coalitions in both countries, we see that in Brazil, the coalitions fighting for the Amazon forest are always highly multiscalar, with strong connections from very local actors to international ones. Amapa is only one territory among others interested in such claims. On the other hand, as French Guiana is the only French territory in the Amazon, the coalitions built were mainly local ones, trying to mobilize international agreements to give value to their claims at the national political level.

\subsection{Discussion on hypotheses}

We are now going to go back over each of our hypotheses.

H1. Coalitions of actors at the origin of protected areas creation were all opposed to destruction of forestland but don't necessarily share the same objectives.

All the coalitions studied have in common the fact that they defend the maintenance of forestland. Indeed, protected areas are generally acknowledged to be an efficient way to fight deforestation (Bruner et al., 2001; Nagendra, 2008; Naughton-Treves et al., 2005). However, establishing a strictly protected area, an indigenous territory, or a public forest for sustainable management does not involve the same perception of what a " preserved ecosystem » has to be.

In strictly protected areas, ecosystems must look as much as possible like a natural forest with no human impact: the objective is to preserve very high levels of biodiversity in all components of ecosystem (fauna, flora, soils, etc.). In protected areas for traditional populations, the objective is to maintain the functions of the ecosystems to enable preservation of traditional populations' way of life: this means preserving big enough animal and plant populations and sufficient water quality to meet the needs of the indigenous populations. However, the ecosystems may be disturbed by agriculture, hunting, and fishing, under thresholds that are considered sustainable by the inhabitants. Finally, in forest management areas, the sustainability targeted is an economic one, based on the exploitation of forest products (mainly wood). Therefore, the main environmental objective is the long-term preservation of wood resources. The other components of the ecosystem (fauna, flora, rivers, etc.) may be taken into account but in a more marginal way. Finally, the core values mobilised by the coalitions defines what environmental results we can probably expect from the different management arrangements.

Therefore, there are also clashes between these coalitions in the more specialised conservation sub-policy field. Each coalition presents its core values and associated tools as the best way to indeed protect the forest. Many studies exist (presenting contrasted results) in order to show what type of protected areas are more 
efficient that the others (Schwartzman et al., 2000; Hayes, 2006; Nepstad et al., 2006; Berkes, 2007; Shahabuddin and Rao, 2010; Porter-Bolland et al., 2012). Since the 1990, the mainstream discourse in the conservation sub-policy field is based on local populations and economic valuation of natural resources.

However, if debates keep going on, all of these models today coexist on territories as the result of the action of the various coalitions. Integrative initiatives recognize the legitimacy of each of them in different situations, like the Brazil National plan of protected areas, or the I.U.C.N. international classification.

H2. The success of coalitions to build the protected area they promote depends on internal and external factors.

The transformation of a new idea into a public policy depends on the policy subsystem ability to recognize it as legitimate. As we can see in Table 7 it often takes a very long time to happen. We can confirm indeed that the success of the coalition depends both on internal and external factors. The internal factors are mainly the capacity of the coalition to integrate new relevant allies in order to get the best adaptative strategic assets (Nicolle, 2014). However, in most of our case studies, an external event was needed to make the difference and allow the apparition of the new protected area. Most often, it was linked to an environmental event at the international level, where national states take engagements towards the international community.

We observed two main situations:

1. A coalition is claiming for a change in public policy and the external event allows their claims to be accepted on the political scene. It was mainly the case for strictly protected areas in both territories, and indigenous territories in Brazil.

2. The external event happens first and an existing economic coalition adapt to produce an environmental change and a new public policy. It was the case for the sustainable forest management. In this case, there are only secondary modification and no deep change of the core beliefs of the coalition.

In our cases, it is important to notice that in the sub-policy field of territorial management, the success of a coalition to create a policy is hardly ever in direct opposition to another existing policy. Trade-off are often found between economic development and conservation policies, either when drawing the geographic limits (for example excluding mining zones from protected areas), or when defining the management rules (for example, in sustainable management forest area, mining activities are potentially allowed).

Finally, creating a protected area is a highly strategic process in which coalitions defend their interest by using all internal and external action opportunities at various levels (local, national, international).

H3. The action capacity of the protected areas depends on the strength of pleading coalitions.

Our diachronic analysis has shown that for the same paradigm, the coalitions' capacity to structure themselves, and to mobilize resources that are relevant in a particular context (partnerships, legal resources, scientific data, etc.) is extremely important in order to effectively transform public policy. Table 8 illustrates the main characteristics of each of the management arrangements that emerged of the action of the coalitions studied. It shows that strictly protected areas share more or less the same characteristics in France and Brazil. However, the other protected areas inherited of the assets and weaknesses of the coalitions that proposed them in each specific national context. For example, in Brazil, the coalitions which defended the indigenous population's rights, were well structured with correspondents based on the local to the international level, and mobilised NGOs, researchers, and the media. The same rallying did not occur in French Guiana, and if Amerindian populations benefitted from specific management arrangements, their rights are less recognized, and they do not have the same autonomy to implement environmental management in their territories.

On the other hand, the forest coalition in French Guiana inherited strong historical legitimacy thanks to the presence of the National Forest Office at the local level (control of land tenure) and at the national level (as a historical actor in French forest management). The progressive shift of the paradigms towards the inclusion of environmental issues (due to international pressure), as well as the implementation of serious forestry research enabled the implementation of management arrangements that are indeed likely to protect forest ecosystems in the long term. The model of public forest management currently tested in Amapa is based on economic profitability: the environmental claims of the coalition who support this model are about limiting massive deforestation in the Amazon. Locally, the skills and the human resources required for the implementation of a sustainable forest management are still limited. Today, French Guiana's public forest managers have more assets at their disposal to implement sustainable forest exploitation than the managers of the public forest created in Amapa, regarding the experience of the forest institute, the technical criteria used and the financial involvement of the government.

4.3. Further developments of the research: actor based analysis for protected areas strategic environmental assessment

Our analysis of coalitions allows us to understand the historical roots of protected areas, and how they produce different management arrangements. The next step of the analysis would be to observe how these differences provide more or less strategic margins of action to the protected area for the protection of ecosystems in the day-to-day management.

Since the years 1990, evaluation of protected areas efficiency became a very important stake, and methodological guidelines and frameworks were developed. It is now recognized that the effectiveness of protected areas in conserving biodiversity is not only a matter of number, size or integrity but also a product of their management (Anthony, 2014). It gave birth to numerous methods aiming at assessing the quality of the management of protected areas. Some of these methods based in indicators grids were inspired from preexisting evaluation logics developed for firm strategies. We can cite the M.E.T.T. (WWF, 2007) or R.A.P.P.A.M. (Ervin, 2003) methods, or even declinations of Balanced Scorecard, adapted to environmental public management (Guimaraes et al., 2010), or to protected area management (Fritz-Vietta et al., 2008). These evaluations built on the basis of synthetic numeric indicators present a clear interest for helping managers to negociate their financial and organisational needs, or to prioritize investments and decisions.

However, we believe that these methods are not sufficient to assess the environmental efficiency of the protected areas. Indeed, they often focus on numerical indicators of management actions, and don't allow to grasp strategic dynamics of (i) management arrangements and (ii) ecosystems degradation causes. Therefore, like Mermet et al. (2010), we think that in order to make a strategic assessment of the environmental effectiveness of protected areas, actor-based approaches and field-work investigations are needed. After analysing the long-term process of protected areas creation 
Comparison of the characteristics of protected areas in Amapa and French Guiana

\begin{tabular}{|c|c|c|c|}
\hline AMAPA & Strict Protection (S.P.A.) & Tribal population (T.P.A.) & Forest management (P.F.M.A.) \\
\hline No of areas & 6 & 4 & 2 \\
\hline Creation (year) & $1980<2002$ & $1982 / 1996$ & 1989,2006 \\
\hline $\begin{array}{l}\text { Total area protected } \\
\left(\mathrm{km}^{2}\right)\end{array}$ & 47,490 & 11,250 & 28,000 \\
\hline Land property & Public (Federal) & Public (Federal) & Public (Federal and regional) \\
\hline $\begin{array}{l}\text { Employees per area } \\
\text { (nb) }\end{array}$ & 3 to 7 & $\sim 20$ & 87 ( 15 directly involved in forest management) \\
\hline \multirow[t]{2}{*}{ Legislative content } & Forbid all direct exploitation of & All natural resources (apart from mining and energy) & No permanent deforestation allowed. Other activities \\
\hline & natural resources & are managed by indigenous people. & may be allowed (zoning) \\
\hline Institutional structure & Public institution (I.C.M. Bio) & Public institution (F.U.N.A.I.) & $\begin{array}{l}\text { Public institutions (federal and local) deliver } \\
\text { concessions to private actors. }\end{array}$ \\
\hline $\begin{array}{l}\text { Main assets for envt. } \\
\text { protection }\end{array}$ & $\begin{array}{l}\text { Law } \\
\text { Large areas }\end{array}$ & $\begin{array}{l}\text { Constitutional recognition } \\
\text { Active local organisations } \\
\text { Support from NGOs. }\end{array}$ & $\begin{array}{l}\text { Control of public land; } \\
\text { Maintenance of forest cover. }\end{array}$ \\
\hline $\begin{array}{l}\text { Main weaknesses for } \\
\text { envt. protection }\end{array}$ & $\begin{array}{l}\text { Control capacity; } \\
\text { Human resources }\end{array}$ & Population growth and changing habits & $\begin{array}{l}\text { Opening of unfragmented forest. } \\
\text { High expectations in terms of economic gains } \\
\text { No limitation of mining activity. }\end{array}$ \\
\hline F. GUIANA & Strict Protection (S.P.A.) & Tribal population (T.P.A.) & Forest management (P.F.M.A.) \\
\hline $\mathrm{N}$ of areas & 7 & 15 & 1 \\
\hline Creation (year) & $1992 / 2006$ & $1991<1995$ & New delimitation and rules: 2006 \\
\hline $\begin{array}{l}\text { Total area protected } \\
\qquad\left(\mathrm{km}^{2}\right)\end{array}$ & 4070 & 6570 & 23,000 \\
\hline Land property & Public (Central state) & Public (central state) & Public (Central state) \\
\hline $\begin{array}{l}\text { Employees per area } \\
\qquad(\mathrm{nb})\end{array}$ & 1 to 9 & 0 & 80 (50 directly involved in forest management) \\
\hline \multirow[t]{2}{*}{ Legislative content } & Forbid nearly all direct exploitation & Allow some subsistence use of natural resources for & No permanent deforestation allowed. Other activities \\
\hline & of natural resources & communities. & may be allowed (zoning) \\
\hline Institutional structure & $\begin{array}{l}\text { Central state finances but } \\
\text { delegates management activities }\end{array}$ & No institutional support & $\begin{array}{l}\text { National public institution is responsible for the } \\
\text { management. Wood is sold to private actors. }\end{array}$ \\
\hline $\begin{array}{l}\text { Main assets for envt. } \\
\text { protection }\end{array}$ & Law & None & $\begin{array}{l}\text { Control of public land; } \\
\text { Maintenance of forest cover; } \\
\text { Use of limited impact practices. }\end{array}$ \\
\hline $\begin{array}{l}\text { Main weaknesses for } \\
\text { envt. protection }\end{array}$ & $\begin{array}{l}\text { Capacity for control on the field; } \\
\text { Limited human resources }\end{array}$ & $\begin{array}{l}\text { Weak recognition; } \\
\text { Weak political organization } \\
\text { Little implementation }\end{array}$ & $\begin{array}{l}\text { Opening of unfragmented forest. } \\
\text { No limitation of mining activity. }\end{array}$ \\
\hline
\end{tabular}

and the resulting management arrangements, the next step would be to analyse how these management arrangements can actually act in order to ensure ecosystem protection in a given pressure context. This only makes sense with a parallel long-term monitoring of the state of the ecosystems.

\section{Conclusion}

All protected areas in French Guiana and in the Amapa are the result of the action of coalitions that include heterogeneous actors (scientists, politics, state representatives, NGOs, local populations, medias ...). Each of these coalitions is structured around common values and common public policy tools to implement these values. If they all promote territorial management arrangements that aim at limiting Amazonian deforestation, they all have different views on what is the best way to do so.
In strictly protected areas, the objective is to preserve very high levels of biodiversity by preventing human activities; in protected areas for traditional populations, the objective is to give people autonomy to use the ecosystems in their traditional way; and in sustainable forest management areas, the objective of sustainable forest exploitation is to preserve long-term timber resources for economic purposes.

All of the coalitions we have described have suceeded to a certain stage and the protected areas resulting from their action today coexist today on these territories. The degree of mobilisation needed for the claims to be transformed into an effective public policy was proportional to the opposition they have encountered. 
We showed that international environmental events were key factors to allow the concretization of coalitions' ideas at the national level. Finally, we have shown why, according to the national socio-political context, advocacy coalitions promoting similar ideas do not have the same strength, and therefore do not have the same impact on the implementation of public policy.

\section{Acknowledgements}

This work benefited from the support of "Investissements d'avenir" of the French National Agency for Research (Ceba, ref. ANR-10-LABX-25-01 and Labex DRIIHM).

\section{References}

Addison, P.F.E., Flanders, L.B., Cook, C.N., 2015. Are we missing the boat? Current uses of long-term biological monitoring data in the evaluation and management of marine protected areas. J. Environ. Manag. 149, 148e156.

Allendorf, T.D., Aung, M., Songer, M., 2012. Using residents' perceptions to improve park-people relationships in Chatthin Wildlife Sanctuary, Myanmar. J. Environ. Manag 99, 36e 43 .

Anthony, B., 2014. Review of International Protected Area Management Effectiveness Experience. Central European University.

Aparecida de Mello, N., Thery, H., 2003. L'Etat bresilien et l'environnement en Amazonie: e volutions, contradictions et conflits. Esp. Ge ogr. 32, 3e20. Apostolopoulou, E., Drakou, E.G., Pediaditi, K., 2012. Participation in the management of Greek Natura 2000 sites: evidence from a cross-level analysis. J. Environ. Manag. 113, 308e318.

Arjunan, M., Holmes, C., Puyravaud, J.-P., Davidar, P., 2006. Do developmental initiatives influence local attitudes toward conservation? A case study from the KalakadeMundanthurai Tiger Reserve, India. J. Environ. Manag 79, 188 e 197.

Aung, M., Khaing Swe, K., Oo, T., Kyaw Moe, K., Leimgruber, P., Allendorf, T., Duncan, C., Wemmer, C., 2004. The environmental history of Chatthin Wildlife Sanctuary, a protected area in Myanmar (Burma). J. Environ. Manag 72, $205 \mathrm{e} 216$.

Banerjee, S.B., 2003. Who sustains whose development? Sustainable development and the reinvention of nature. Organ. Stud. 24, $143 \mathrm{e} 180$.

Barreto, P., Veríssimo, A., 2002. Informaçoes e sugestoes para a criaçao e gestao de florestas públicas na Amazônia. MMA, Brasilia.

Berkes, F., 2007. Community-based conservation in a globalized world. Proc. Natl. Acad. Sci. U. S. A. 104, 15188e 15193.

Borderes, M., 2003. Les problematiques de gestion durable du massif forestier guyanais. Rev. For. Fr. 55, 219e 235

Boudoux d'Hautefeuille, M., 2012. Entre marge et interface, recompositions territoriales a la frontiere franco-bresilienne (Guyane/Amapa). PhD Thesis. Universite Antilles-Guyane, Schoelcher.

Brown, J.C., Purcell, M., 2005. There's nothing inherent about scale: political ecology, the local trap, and the politics of development in the Brazilian Amazon. Geoforum 36 (5), 607e624.

Bruner, A.G., Gullison, R.E., Rice, R.E., Da Fonseca, G.A.B., 2001. Effectiveness of parks in protecting tropical biodiversity. Science. 291, $125 \mathrm{e} 128$.

Buisson, E., Dutoit, T., 2006. Creation of the natural reserve of La Crau: implications for the creation and management of protected areas. J. Environ. Manag. 80, 318 e 326.

Calado, H., Bragagnolo, C., Silva, S., Vergilio, M., 2016. Adapting environmental function analysis for management of protected areas in small islands e case of Pico Island (the Azores). J. Environ. Manag. 171, 231 e242.

Campos, P.H.P., 2009. As origens da internacionalizaçao das empresas de engenharia brasileiras. In Expressao popular, Empresas transnacionais brasileiras na america latina: um debate necessario. Expressao popular, Sao Paulo.

Cook, C.N., Carter, R.W., Hockings, M., 2014. Measuring the accuracy of management effectiveness evaluations of protected areas. J. Environ. Manag. 139, 164e171.

Cornejo, E., Fungairino, S.G., Barandica, J.M., Serrano, J.M., Zorrilla, J.M., Gomez, T., Zapata, F.J., Acosta, F.J., 2016. Conceptual basis for an integrated system for the management of a protected area. Examples from its application in a mediterranean area. J. Environ. Manag. 166, 237 e249.

D'Antonio, A., Monz, C., Newman, P., Lawson, S., Taff, D., 2013. Enhancing the utility of visitor impact assessment in parks and protected areas: a combined socialeecological approach. J. Environ. Manag 124, 72e81.

Del Carmen Sabatini, M., Verdiell, A., Rodríguez Iglesias, R.M., Vidal, M., 2007. A quantitative method for zoning of protected areas and its spatial ecological implications. J. Environ. Manag 83, $198 \mathrm{e} 206$.

Drummond, J.A., Franco, J.L.F.A., 2013. Nature Protection: the FBCN and Conservation Initiatives in Brazil, 1958-1992, pp. 338e367. HALAC. 2

Dumez, H., 2013. Methodologie de la recherche qualitative. Magnard-Vuibert, Paris.

Ervin, J., 2003. Rapid Assessment and Prioritization of Protected Area Management WWF International, Gland, Switzerland.

Fritz-Vietta, N., R6ttger, C., Stoll-Kleemann, S., 2008. Enhancing Management Effectiveness in the Biosphere Reserve Mananara-Nord. Discussion Paper 02 of the GoBi Research Group, Greifswald, April 2008.

Grenand, F., Grenand, P., 2005. Trente ans de luttes amerindiennes. Ethnies 31, $132 \mathrm{e} 163$.

Guimaraes, B., Simoes, P., Marques, R.C., 2010. Does performance evaluation help public managers? A Balanced scorecard approach in urban waste services. J. Environ. Manag. 91, 2632e2638.

Hayes, T.M., 2006. Parks, people, and forest protection: an institutional assessment of the effectiveness of protected areas. World Dev. 34, 2064e2075.

Hutton, J., Adams, W.M., Murombedzi, J.C., 2005. Back to the Barriers? Changing narratives in biodiversity conservation. Forum Dev. Stud. 32, 341e370.

Jones, N., Clark, J.R.A., Panteli, M., Proikaki, M., Dimitrakopoulos, P.G., 2012. Local social capital and the acceptance of Protected Area policies: an empirical study of two Ramsar river delta ecosystems in northern Greece. J. Environ. Manag 96, $55 \mathrm{e} 63$.

Kidd, A.M., Monz, C., D'Antonio, A., Manning, R.E., Reigner, N., Goonan, K.A., 
Jacobi, C., 2015. The effect of minimum impact education on visitor spatial behavior in parks and protected areas: an experimental investigation using GPS-based tracking. J. Environ. Manag 162, 53 e62.

Leroy, M., Derroire, G., Lemenager, T., Vende, J., 2014. Sustainable Management of Tropical Forests - from a Critical Analysis of the Concept to an Environmental Evaluation of its Management Arrangements. AFD, Paris.

Lezy, E., 2000. Guyane, Guyanes. une geographie « sauvage » de l'Orenoque a l'Amazone. Belin, Paris.

Lin, J., Li, X., 2016. Conflict resolution in the zoning of eco-protected areas in fastgrowing regions based on game theory. J. Environ. Manag. 170, 177e185.

Liu, J., Ouyang, Z., Miao, H., 2010. Environmental attitudes of stakeholders and their perceptions regarding protected area-community conflicts: a case study in China. J. Environ. Manag. 91, 2254e2262.

Lopez y Royo, C., Silvestri, C., Pergent, G., Casazza, G., 2009. Assessing humaninduced pressures on coastal areas with publicly available data. J. Environ. Manag 90, 1494e1501.

Mermet, L., Bille, R., Leroy, M., 2010. Concern-focused evaluation for ambiguous and conflicting policies: an approach from the environmental field. Am. J. Eval. 31, $180 \mathrm{e} 198$.

Nagendra, H., 2008. Do parks work? Impact of protected areas on land cover clearing. AMBIO 37, 330e337.

Naughton-Treves, L., Holland, M.B., Brandon, K., 2005. The role of protected areas in conserving biodiversity and sustaining local livelihoods. Annu. Rev. Environ. Resour. 30, 219e252.

Nepstad, D., Schwartzman, S., Bamberger, B., Santilli, M., Ray, D., Schlesinger, P. Lefebvre, P., Alencar, A., Prniz, E., Fiske, G., 2006. Inhibition of Amazon deforestation and fire by parks and indigenous lands. Conserv. Biol. 20, 65e73.

Nicolle, S., 2014. Les espaces naturels prote ges en foret amazonienne. Des doctrines de gestion aux dispositifs: quelle efficacite pour la gestion de l'environnement? Etude comparative France (Guyane)/Bresil (Amapa). Ph.D Thesis. Universite des Antilles et de la Guyane.

Olivier De Sardan, J.P., 2015. Epistemology, Fieldwork and Anthropology. Palgrave, UK.

Porter-Bolland, L., Ellis, E.A., Guariguata, M.R., Ruiz-Mallen, I., NegreteYankelevich, S., Reyes-García, V., 2012. Community managed forests and forest protected areas: an assessment of their conservation effectiveness across the tropics. For. Ecol. Manag. 268, 6e17.

Sabatier, P., 1988. An advocacy coalition framework of policy change and the role of policy-oriented learning therein. Policy Sci. 21, 129e168.

Sabatier, P., Weible, C., 2007. The advocacy coalition framework. Innovations and clarifications. In: Sabatier, P. (Ed.), Theories of the Policy Process. Westviewpress, California, pp. 195e227.

Sanite, L., 1992. Pre-rapport sur la conservation et la gestion du patrimoine Guyanais. Comite de la culture, de l'education et de l'environnement, Cayenne.

Sarvasova, Z., Salka, J., Dobsinska, Z., 2013. Mechanism of cross-sectoral coordination between nature protection and forestry in the Natura 2000 formulation process in Slovakia. J. Environ. Manag 127, 65 e 72.

Schwartzman, S., Moreira, A., Nepstad, D., 2000. Rethinking tropical forest conservation: perils in parks. Conserv. Biol. 14, 1351e1357.

Shahabuddin, G., Rao, M., 2010. Do community-conserved areas effectively conserve biological diversity? Global insights and the Indian context. Biol. Conserv. 143, 2926 e 2936.

Sotirov, M., Memmler, M., 2012. The Advocacy Coalition Framework in natural resource policy studiesdrecent experiences and further prospects. For. Policy Econ. 16, 51 e64.

Taravella, R., De Sartre, X.A., 2006. Entre developpement et conservation: une comprehension de la schizophrenie des politiques amazoniennes en train de se faire. In: Van Eeuwen, Daniel (Ed.), Le nouveau Bresil de Lula. Editions de l'Aube, France, pp. 181e197.

W.W.F, 2007. Management Effectiveness Tracking Tool: Reporting Progress at Protected Area Sites, second ed. World Wildlife Fund, Gland, Switzerland. 